\title{
Stripped Sour Water Treatment by Advanced Oxidation Processes
}

\author{
José R. Guimarães, * Mirthys C. Gasparini, Milena G. Maniero and \\ Carlos G. N. Mendes
}

\author{
School of Civil Engineering, Architecture and Urbanism, University of Campinas, \\ Av. Albert Einstein, 951, CP 6021, 13083-852 Campinas-SP, Brazil
}

No presente trabalho foi avaliada a aplicação dos processos de fotólise (UV), peroxidação $\left(\mathrm{H}_{2} \mathrm{O}_{2}\right)$, peroxidação assistida por radiação ultravioleta $\left(\mathrm{UV} / \mathrm{H}_{2} \mathrm{O}_{2}\right)$, reagente de Fenton $\left(\mathrm{H}_{2} \mathrm{O}_{2} / \mathrm{Fe}(\mathrm{II})\right)$ e foto-Fenton $\left(\mathrm{H}_{2} \mathrm{O}_{2} / \mathrm{Fe}(\mathrm{II}) / \mathrm{UV}\right)$ no tratamento de água ácida retificada proveniente da Refinaria de Petróleo Replan da Petrobras, Paulínia-SP. Para avaliação da eficácia dos processos, a concentração de carbono orgânico dissolvido (COD) foi monitorada durante todo o período de reação. Dentre os processos avaliados, a peroxidação assistida por radiação ultravioleta apresentou o melhor potencial para sua aplicação no tratamento da água ácida retificada.

This study assessed the application of photolysis (UV), peroxidation $\left(\mathrm{H}_{2} \mathrm{O}_{2}\right)$, peroxidation combined with ultraviolet light $\left(\mathrm{UV} / \mathrm{H}_{2} \mathrm{O}_{2}\right)$, Fenton's reagent $\left(\mathrm{H}_{2} \mathrm{O}_{2} / \mathrm{Fe}(\mathrm{II})\right)$ and photo-Fenton $\left(\mathrm{H}_{2} \mathrm{O}_{2} / \mathrm{Fe}(\mathrm{II}) / \mathrm{UV}\right)$ processes in the treatment of stripped sour water from the Petrobras Replan Oil Refinery in Paulínia City, São Paulo State, Brazil. To evaluate the efficiency of the process, the concentration of dissolved organic carbon (DOC) was monitored throughout the reaction period. Among the evaluated processes, peroxidation combined by ultraviolet radiation showed the best potential for its application in the stripped sour water treatment.

Keywords: Fenton, oil refinery, photo-Fenton, reuse, $\mathrm{UV} / \mathrm{H}_{2} \mathrm{O}_{2}$

\section{Introduction}

The oil refining industry uses a large amount of water in its production process, generating a large volume of effluent. At the Replan Refinery in Paulínia City (São Paulo State, Brazil), $700 \mathrm{~L}$ of water are consumed per $1000 \mathrm{~L}$ of oil processed. There is a great interest in improving wastewater management in petrochemical facilities by optimizing water use and introducing technologies which enable water to be reused in production units. ${ }^{1}$

Sour water is one of the most significant issues in a refinery mainly due to its composition and its corrosive nature. It is produced by various different processes and thus its composition varies. In addition, the management cost of this type of water is quite high. Sour water is defined as any processed water containing hydrogen sulfide, ammonia, phenols, cyanides, dissolved oils, mercaptans, hydrocarbons, suspended solids and high levels of dissolved organic carbon (DOC) and chemical oxygen demand (COD). ${ }^{2}$ It usually has $\mathrm{pH}$ values above

*e-mail: jorober@fec.unicamp.br
7, though it gets its name from its characteristic smell. Sour water may result from water vapor injected into oil processing units in order to reduce the partial pressures of hydrocarbons, which provides less extreme temperature conditions. Some is generated by injection of wash water to prevent salt deposition inside pipes or equipment such as heat exchangers. According to Coelho et al., ${ }^{3}$ typical sour water production in large refineries is between 0.2 and 0.5 $\mathrm{m}^{3}$ ton $^{-1}$ of crude oil processed.

Sour water is typically not treated along with the effluents from the refinery. It is separated and stripped in order to remove sulfide and ammonia, so they can be reused in the refining process. Though stripped sour water from the Petrobras Replan Refinery in Paulínia City is $\mathrm{H}_{2} \mathrm{~S}$-free, it contains high levels of ammonia, mercaptans and hydrocarbons, in addition to oils and greases. For this reason, it is not possible to reuse all the sour water produced at Replan.

Due to the great variety of recalcitrant compounds in stripped sour water, studies are needed to look for clean and efficient treatment alternatives that compensate for the limitations of conventional methods when the effluent 
is intended to be reused. Advanced oxidation processes (AOPs) are technologies that involve the generation of hydroxyl radicals $\left({ }^{\circ} \mathrm{OH}\right)$, which are highly oxidizing and non-selective. Due to their high reactivity, these radicals can react with a wide variety of complex organic compounds, oxidizing them to simple molecules, or even mineralizing them. ${ }^{4,5}$

Biodegradation, ${ }^{6}$ membrane bioreactor methods, ${ }^{7}$ electrocoagulation, ${ }^{8}$ enhanced photo-degradation, ${ }^{9}$ electrochemical methods, ${ }^{10,11}$ microwave-assisted catalytic wet air oxidation ${ }^{12}$ and photocatalytic degradation methods ${ }^{1}$ are used for the treatment of effluents from oil refineries. However, there are still few works about sour water treatment in scientific literature.

Coelho et al. ${ }^{3}$ evaluated reduction of DOC from sour water from a petroleum refinery by several oxidation processes and verified that Fenton and photo-Fenton led to the best results. Bhargava et al. ${ }^{13}$ employed the catalytic wet oxidation process for treating stripped sour water from an oil shale refinery in Australia, with a $9 \mathrm{~g} \mathrm{~L}^{-1} \mathrm{DOC}$ initial concentration, and they reduced DOC by $73 \%$ after a $3 \mathrm{~h}$ reaction at $200{ }^{\circ} \mathrm{C}$ using a copper and palladium bimetallic catalyst. Prasad et al. ${ }^{14}$ adopted the wet oxidation with hydrogen peroxide technique to treat the same effluent used by Bhargava et al..$^{13}$ DOC removal was $80 \%$ in $1.5 \mathrm{~h}$ at $150{ }^{\circ} \mathrm{C}$, using $64 \mathrm{~g} \mathrm{~L}^{-1}$ of $\mathrm{H}_{2} \mathrm{O}_{2} \cdot{ }^{14}$

It is also important to emphasize that studies based on treatment of industrial effluents for the purpose of reusing them in the production process have become very important. Reusing treated water consolidates alternatives and actions that use water more rationally, minimizing waste. Among various published works, Ismail and Al-Hashimi, ${ }^{15}$ El-Salam and El-Naggar, ${ }^{16}$ Oliveira et al..$^{17}$ and de Feo et al. ${ }^{18}$ reported reuse proposals in different kinds of industrial plants.

The objective of this study was to evaluate reduction of dissolved organic carbon present in stripped sour water flow by five processes: photolysis (UV), peroxidation $\left(\mathrm{H}_{2} \mathrm{O}_{2}\right)$, peroxidation with ultraviolet radiation $\left(\mathrm{UV} / \mathrm{H}_{2} \mathrm{O}_{2}\right)$, Fenton's reagent $\left(\mathrm{H}_{2} \mathrm{O}_{2} / \mathrm{Fe}(\mathrm{II})\right)$ and photo-Fenton $\left(\mathrm{H}_{2} \mathrm{O}_{2} / \mathrm{Fe}(\mathrm{II}) / \mathrm{UV}\right)$. The effects of initial concentrations of hydrogen peroxide and ferrous ions (Fe(II)) on the treatment of this effluent were also investigated.

\section{Experimental}

\section{Reagents and effluent}

Ferrous sulfate heptahydrate $\left(\mathrm{FeSO}_{4} \cdot 7 \mathrm{H}_{2} \mathrm{O}\right)$, concentrated sulfuric acid and hydrogen peroxide (30\% v/v) were supplied by Synth (Diadema, Brazil).
Stripped sour water samples from the Replan Refinery in Paulínia City were collected and transferred to the Laboratory of Oxidation Processes (LABPOX) of the Department of Sanitation and Environment (DSA) (School of Civil Engineering, Architecture and Urbanism, at University of Campinas (Unicamp)). The sample was characterized (Table 1) and stored in a refrigerator (ca. $10{ }^{\circ} \mathrm{C}$ ).

Table 1. Characterization of stripped sour water sample

\begin{tabular}{lcc}
\hline Parameters & Values & Units \\
\hline COD & 553 & $\mathrm{mg} \mathrm{O}_{2} \mathrm{~L}^{-1}$ \\
BOD & 147 & $\mathrm{mg} \mathrm{O}_{2} \mathrm{~L}^{-1}$ \\
DOC & 160.5 & $\mathrm{mg} \mathrm{L}^{-1}$ \\
EC & 396 & $\mu \mathrm{S} \mathrm{cm}^{-1}$ \\
$\mathrm{pH}$ & 9.5 & \\
Turbidity & 30 & $\mathrm{UT}$ \\
Apparent color & 624 & PtCo \\
\hline
\end{tabular}

Notable levels of COD, BOD (biochemical oxygen demand) and DOC were found, suggesting the presence of dissolved oil, phenols and hydrocarbons. The low $\mathrm{BOD} / \mathrm{COD}$ ratio (0.27) indicates the low biodegradability of this effluent. The $\mathrm{pH}$ value is high because caustic soda is added to remove ammonia gas in the stripping tower. The electrical conductivity (EC) value might indicate the presence of salts dissolved in the sample. The effluent had pink-orange coloring.

\section{Experimental system}

The batch system used in this study is presented in Figure 1 . The batch was made using a photochemical reactor, a magnetic stirrer, a $600 \mathrm{~mL}$ vessel and a peristaltic

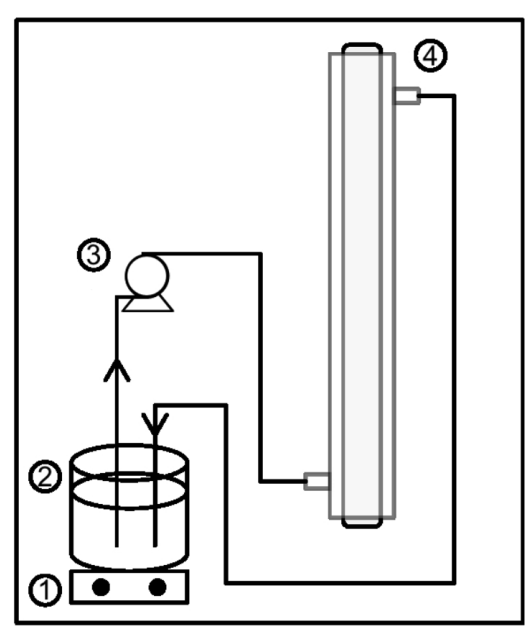

Figure 1. Experiment setup: (1) magnetic stirrer, (2) vessel, (3) peristaltic pump and (4) photochemical reactor. 
pump to recirculate the solution at a flow of approximately $207 \mathrm{~mL} \mathrm{~min}^{-1}$. This system was based on works by da Silva et al. ${ }^{19}$ and Guimarães et al. ${ }^{20}$

The bench photochemical reactor consisted of a $42.5 \mathrm{~cm}$ long and $4 \mathrm{~cm}$ internal diameter borosilicate glass cylinder with a low pressure mercury vapor lamp inserted in the center $\left(15 \mathrm{~W}, \lambda_{\max }\right.$ of $254 \mathrm{~nm}, 2.5 \mathrm{~cm}$ internal diameter, brand Ecolume). The lamp was in direct contact with the circulating solution. The internal volume of the reactor was approximately $270 \mathrm{~mL}$. The radiation intensity (I) of the UV lamp was $8.3 \mathrm{~mW} \mathrm{~cm} \mathrm{~cm}^{-2}$. It was obtained by a VLX $3 \mathrm{Wr}$ model Cole Parmer radiometer calibrated to $254 \mathrm{~nm}$.

In this experimental system, the effluent was continuously stirred inside the vessel, pumped into the reactor with an upward flow and returned to the vessel, forming a closedcircuit. In tests using UV radiation, the UV light exposure time of the effluent was different from the total trial time, and was calculated according to equation 1 .

$\mathrm{t}_{\text {irrad }}=\mathrm{t}_{\text {tot }}\left(\mathrm{V}_{\text {react }} / \mathrm{V}_{\text {sol }}\right)$

in which $t_{\text {irrad }}$ is exposure time to $U V$ radiation ( $\mathrm{min}$ ), $\mathrm{t}_{\text {tot }}$ is total trial time ( $\mathrm{min}), \mathrm{V}_{\text {react }}$ is useful volume of the photolytic reactor $(\mathrm{mL})$ and $\mathrm{V}_{\text {sol }}$ is total volume of the solution $(\mathrm{mL})$.

A volume of $500 \mathrm{~mL}$ of the sample was used in all tests. In peroxidation and $\mathrm{UV} / \mathrm{H}_{2} \mathrm{O}_{2}$ trials, $\mathrm{H}_{2} \mathrm{O}_{2}$ was added once at different DOC: $\mathrm{H}_{2} \mathrm{O}_{2}$ mass ratios between 1:2 and 1:7, giving 360 to $1260 \mathrm{mg} \mathrm{L}^{-1} \mathrm{H}_{2} \mathrm{O}_{2}$ concentrations. For Fenton and photo-Fenton processes, 1:5 and 1:7 DOC: $\mathrm{H}_{2} \mathrm{O}_{2}$ (900 and $1260 \mathrm{mg} \mathrm{L}^{-1} \mathrm{H}_{2} \mathrm{O}_{2}$ ) mass rations were evaluated, and ferrous ion concentration varied from 31 to $500 \mathrm{mg} \mathrm{L}^{-1}$. Photolysis, peroxidation and $\mathrm{UV} / \mathrm{H}_{2} \mathrm{O}_{2}$ trials were performed at the original $\mathrm{pH}$ of the sample, while the value was adjusted to pH 3.0 in Fenton and photo-Fenton processes using diluted sulfuric acid.

Aliquots were collected after $15 \mathrm{~min}$ and every $30 \mathrm{~min}$ thereafter to monitor the concentration of DOC in order to evaluate the effectiveness of procedures. After total reaction time, COD, color, turbidity and electrical conductivity analyses were also performed.

\section{Analytical methods}

A Shimadzu model 5000A total organic carbon analyzer was used for DOC analysis. COD and BOD analyses were performed according to APHA/AWWA/WEF standard methods. $^{21}$

Measurements of hydrogen ionic potential $(\mathrm{pH})$ were performed using the electrometric method, using the ASTM D1293 methodology with a Thermo Orion 410A pH meter. ${ }^{22}$
Turbidity analyses were based on section $2130 \mathrm{~B}$ of the APHA/AWWA/WEF methodology, ${ }^{21}$ using a HACH model $2100 \mathrm{~N}$ turbidimeter. Electrical conductivity measurements were performed according to APHA/AWWA/WEF section $2510 \mathrm{~B}^{21}$ on a Micronal B330 conductivity meter.

Color analyses were performed as defined in section $2120 \mathrm{C}$ of the APHA/AWWA/WEF methodology ${ }^{21}$ using a HACH model DR4000 spectrophotometer.

A colorimetric analytical method was adopted for the determination of hydrogen peroxide. It was based on redox reactions between the solution, which contained $\mathrm{H}_{2} \mathrm{O}_{2}$, and a yellow-colored acidic metavanadate ion solution. Due to the formation of red-orange-colored peroxovanadium cations with maximum absorbance at $450 \mathrm{~nm}$, hydrogen peroxide concentration could be obtained by UV-Vis spectrophotometry. $^{23}$

\section{Results and Discussion}

Photolysis (UV)

DOC reduced by $17 \%$ after 210 min of photolysis. This may be because of the degradation of compounds present in the sample and/or decreased solubility of certain volatile and semi-volatile organic compounds due to the approximately $8{ }^{\circ} \mathrm{C}$ temperature increase during the trial.

COD $(16.4 \%)$ was reduced by a similar amount to DOC. Color was reduced by $58 \%$ and turbidity by $29 \%$. The decreased values for these parameters may be due to the effect of temperature on solubility and to UV radiation modifying the structure or destroying the chromophore groups of a set of molecules present in the effluent that absorb electromagnetic radiation at a wavelength close to $254 \mathrm{~nm}$.

Photolysis was found to reduce DOC by a similar amount by Coelho et al., ${ }^{3}$ who verified reduction of $20 \%$ in treatment of sour water from an oil refinery with initial DOC concentration around $1000 \mathrm{mg} \mathrm{L}^{-1}$.

Peroxidation $\left(\mathrm{H}_{2} \mathrm{O}_{2}\right)$

There was no reduction in DOC concentration in the peroxidation process, showing that the compounds present in stripped sour water cannot be mineralized when only the oxidant hydrogen peroxide is applied.

Both turbidity reduction ( 0 to $5 \%$ ) and $\mathrm{COD}$ ( 0 to $3.3 \%$ ) values were very low. However, this process was able to remarkably reduce the color of the effluent (15 to 21\%). This means that the structure of a set of component molecules of the effluent was modified and their chromophore groups may have been destroyed. 
Coelho et al. ${ }^{3}$ verified that peroxidation reduced DOC of sour water from an oil refinery by only $8 \%$, confirming the results obtained in this work.

\section{Peroxidation combined with ultraviolet light $\left(\mathrm{UV} / \mathrm{H}_{2} \mathrm{O}_{2}\right)$}

According to Figure 2, when DOC: $\mathrm{H}_{2} \mathrm{O}_{2}$ mass ratio was $1: 2$, DOC reduction was $47.5 \%$. At a ratio of $1: 3$, DOC reduction was $60.6 \%$. Both were slower and smaller than the higher ratios in $210 \mathrm{~min}$ of reaction. When the DOC: $\mathrm{H}_{2} \mathrm{O}_{2}$ mass ratio was 1:4, degradation was $82 \%$ for the same reaction time. This showed that a higher $\mathrm{H}_{2} \mathrm{O}_{2}$ concentration had a more pronounced DOC concentration decay curve, i.e., a higher degradation rate of organic compounds. However, this behavior was verified only up to $1: 4 \mathrm{DOC}: \mathrm{H}_{2} \mathrm{O}_{2}$ mass ratio.

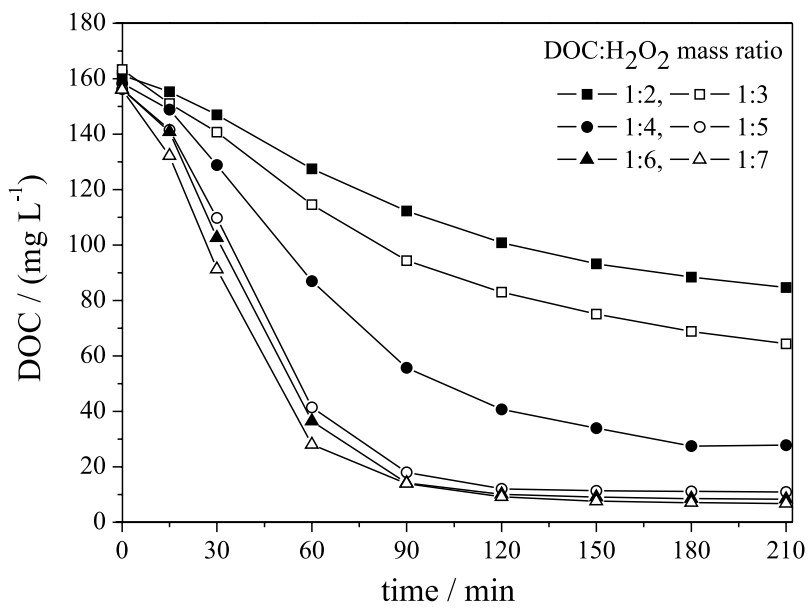

Figure 2. DOC concentration variation over time for degradation by $\mathrm{UV} / \mathrm{H}_{2} \mathrm{O}_{2}$ at different DOC: $\mathrm{H}_{2} \mathrm{O}_{2}$ mass ratios.

No significant differences were noted in DOC reduction among DOC: $\mathrm{H}_{2} \mathrm{O}_{2}$ mass ratios of 1:5, 1:6 and 1:7: maximum organic carbon reduction values were between 93 and $95 \%$ in 150 min of reaction.

Abramovic et al..$^{24}$ observed the same behavior in the degradation of the insecticide thiacloprid: a rapid increase in the reaction rate occurred at $\mathrm{H}_{2} \mathrm{O}_{2}$ concentrations from 0 to $45 \mathrm{mmol} \mathrm{L}^{-1}$ (0 to $1530 \mathrm{mg} \mathrm{L}^{-1}$ ), while for the range of $45-162 \mathrm{mmol} \mathrm{L}^{-1}$ (1530 to $5508 \mathrm{mg} \mathrm{L}^{-1}$ ) only a slight increase was observed. It remained practically constant afterwards. Ghodbane and Hamdaoui ${ }^{25}$ verified that up to the limit of $1543 \mathrm{mg} \mathrm{L}^{-1}$, more color was removed as initial $\mathrm{H}_{2} \mathrm{O}_{2}$ concentration increased, supporting the results obtained here.

According to Silva et al. ${ }^{26}$ and Daneshvar et al.,${ }^{27}$ when there is excess $\mathrm{H}_{2} \mathrm{O}_{2}$, there may be reactions that compete for hydroxyl radicals (equations 2 to 4 ). As a result, increasing hydrogen peroxide concentration does not increase DOC degradation because of competition between the oxidant and the organic compounds by ${ }^{\circ} \mathrm{OH}$. Therefore, there is an optimal concentration of this oxidant at which the photo-oxidation rate is at its maximum.

$$
\begin{aligned}
& \bullet \mathrm{OH}+\mathrm{H}_{2} \mathrm{O}_{2} \rightarrow \mathrm{HO}_{2}^{\cdot}+\mathrm{H}_{2} \mathrm{O} \\
& 2{ }^{\circ} \mathrm{OH} \rightarrow \mathrm{H}_{2} \mathrm{O}_{2} \\
& \mathrm{HO}_{2}+{ }^{\bullet} \mathrm{OH} \rightarrow \mathrm{O}_{2}+\mathrm{H}_{2} \mathrm{O}
\end{aligned}
$$

\section{Fenton's reagent $\left(\mathrm{H}_{2} \mathrm{O}_{2} / \mathrm{Fe}(\mathrm{II})\right)$}

The 1:5, 1:6 and 1:7 DOC: $\mathrm{H}_{2} \mathrm{O}_{2}$ mass ratios were able to reduce more than $90 \%$ of DOC in the $\mathrm{UV} / \mathrm{H}_{2} \mathrm{O}_{2}$ tests, so the 1:5 and 1:7 mass ratios were used in the Fenton tests in order to make a comparison between the processes. Iron concentrations from 31 to $500 \mathrm{mg} \mathrm{L}^{-1}$ were used, thus the oxidant/ferrous ion mass ratios varied from 1.8:1 to 40:1. Optimum $\mathrm{H}_{2} \mathrm{O}_{2}: \mathrm{Fe}$ (II) molar ratios from 1:1 to 400:1 (0.6:1 to $242.8: 1$ mass ratios) have been proposed to degrade different compounds in aqueous solution. ${ }^{28}$

The reaction rate in the first $60 \mathrm{~min}$ for Fenton's reagent was directly proportional to $\mathrm{Fe}$ (II) concentration for both 1:5 and 1:7 DOC: $\mathrm{H}_{2} \mathrm{O}_{2}$ ratios, as shown in Figure 3. This process proved to be very inefficient when low concentrations of ferrous ion $\left(31 \mathrm{mg} \mathrm{L}^{-1}\right)$ were applied, reaching a maximum DOC reduction of only $8 \%$. For initial $\mathrm{Fe}$ (II) contents of 125,250 and $500 \mathrm{mg} \mathrm{L}^{-1}$, DOC reduction was very similar in $120 \mathrm{~min}$ of reaction, ranging from 38 to $45 \%$. These values stabilized after this reaction period.

Other works have also reported DOC removal of around 40\% employing Fenton's reagent for the treatment of effluents. ${ }^{29}$ This may occur due to the formation of carboxylic acids. These treatment-resistant intermediate compounds react very slowly with ${ }^{\circ} \mathrm{OH}$, making the reaction unproductive..$^{30}$ Another possibility is the reaction of Fe(III) ions with these intermediate products, forming stable organic compounds that are difficult to degrade, decreasing the efficiency of the reaction, as shown in equation 5.,29,31

$\mathrm{Fe}(\mathrm{III})+\mathrm{RCO}_{2}^{-} \rightarrow\left[\mathrm{Fe}(\mathrm{III})\left(\mathrm{RCO}_{2}^{-}\right)\right]^{2+}$

For both concentrations of hydrogen peroxide evaluated, DOC reduction was almost the same. Increasing $\mathrm{H}_{2} \mathrm{O}_{2}$ concentration from $900 \mathrm{mg} \mathrm{L}^{-1}\left(1: 5 \mathrm{DOC}: \mathrm{H}_{2} \mathrm{O}_{2}\right.$ ) to $1260 \mathrm{mg} \mathrm{L}^{-1}\left(1: 7 \mathrm{DOC}: \mathrm{H}_{2} \mathrm{O}_{2}\right.$ ) while maintaining the same $\mathrm{Fe}(\mathrm{II})$ content did not significantly improve DOC and COD reduction within the time of the experiment. The highest efficiencies obtained were $49 \%$ for DOC and $81.7 \%$ for COD.

Varying $\mathrm{Fe}$ (II) and $\mathrm{H}_{2} \mathrm{O}_{2}$ concentrations, it was found the same effect by Padoley et al. ${ }^{32}$ assessing Fenton's 

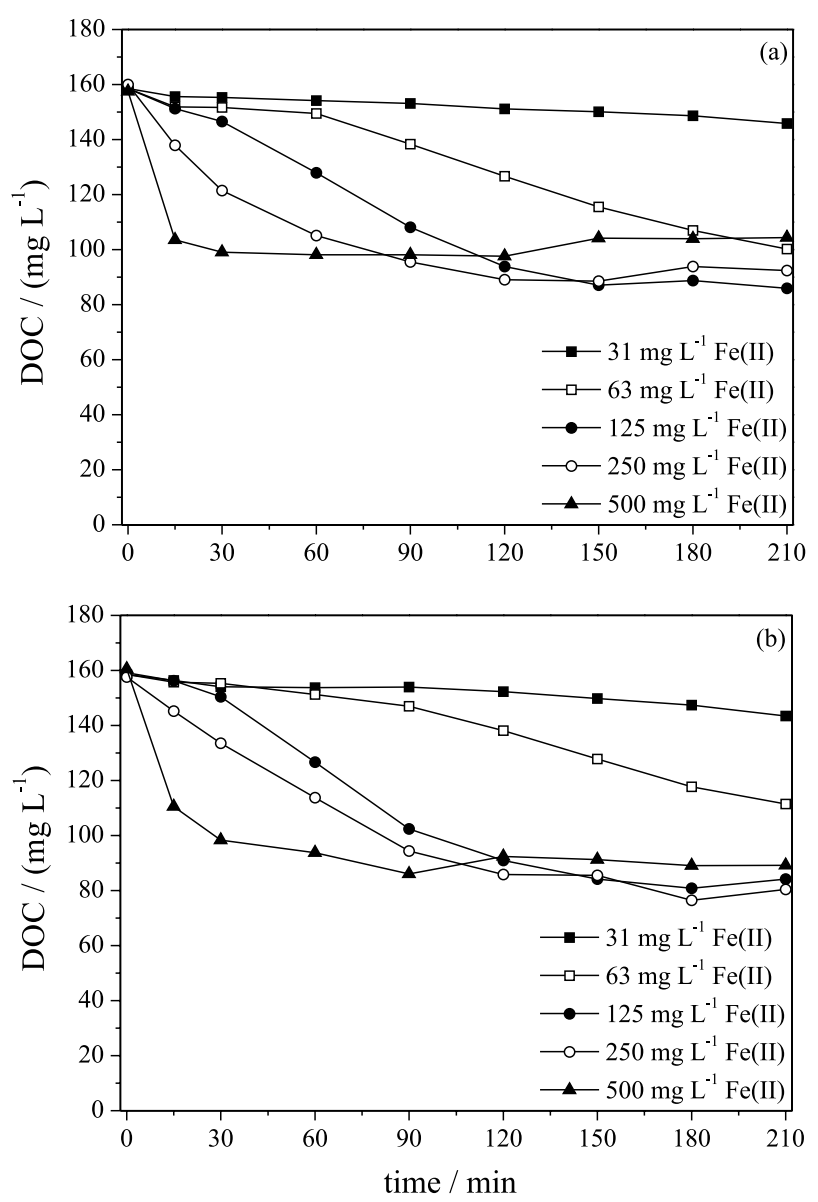

Figure 3. DOC values at different $\mathrm{Fe}(\mathrm{II})$ concentrations over time for (a) 1:5 and (b) 1:7 DOC: $\mathrm{H}_{2} \mathrm{O}_{2}$ mass ratios, for the Fenton process.

reagent as a pretreatment option for 3-cyanopyridine wastewater (which had high ammonia content, alkaline $\mathrm{pH}$ and extremely high COD values). Padoley et al. ${ }^{32}$ verified that more COD was removed when ferrous sulfate concentration was increased up to a ferrous concentration of $2.4 \mathrm{~g} \mathrm{~L}^{-1}$ and increasing hydrogen peroxide concentration over $750 \mathrm{mg} \mathrm{L}^{-1}$ did not result in increasing COD reduction.

\section{Photo-Fenton process $\left(\mathrm{H}_{2} \mathrm{O}_{2} / \mathrm{Fe}(\mathrm{II}) / \mathrm{UV}\right)$}

After the first 60 min of reaction in the photo-Fenton process, DOC removal was inversely proportional to $\mathrm{Fe}(\mathrm{II})$ concentration for both DOC: $\mathrm{H}_{2} \mathrm{O}_{2}$ mass ratios assessed (1:5 and 1:7), as shown in Figure 4. This is different from what happened with Fenton's reagent. It was found that the optimum $\mathrm{Fe}(\mathrm{II})$ concentration was the lowest assessed (31 $\left.\mathrm{mg} \mathrm{L}^{-1}\right)$. The lower concentrations of ferrous ion used resulted in more efficient DOC removal efficiencies since $\mathrm{Fe}(\mathrm{II})$ ions are regenerated by $[\mathrm{Fe}(\mathrm{OH})]^{2+}$ and $\left[\mathrm{Fe}\left(\mathrm{RCO}_{2}\right)\right]^{2+}$ photolysis in the Fenton/photo-Fenton system, among other mechanisms, according to equations 6 and $7.30,33$
$[\mathrm{Fe}(\mathrm{OH})]^{2+}+\mathrm{h} v \rightarrow \mathrm{Fe}(\mathrm{II})+{ }^{\circ} \mathrm{OH}$

$\left[\mathrm{Fe}\left(\mathrm{RCO}_{2}\right)\right]^{2+}+\mathrm{h} \nu \rightarrow \mathrm{Fe}(\mathrm{II})+\mathrm{CO}_{2}+\cdot \mathrm{R}$

It is possible that so many hydroxyl radicals are formed by the decomposition of $\mathrm{H}_{2} \mathrm{O}_{2}$ in the photo-Fenton process at high $\mathrm{Fe}(\mathrm{II})$ concentrations. Competitive reactions take place consuming a large amount of those hydroxyl radicals (equations 2 to 4 ) before they are effectively used in the degradation of organic compounds. ${ }^{33} \mathrm{High} \mathrm{Fe}(\mathrm{II})$ concentration can result in increased turbidity of the solution, preventing the absorption of the UV radiation necessary for photolysis. In addition, excess Fe(II) ions can scavenge hydroxyl radicals. ${ }^{31,33-36}$

The test lasted $150 \mathrm{~min}$. At this point, there was no notable difference between DOC reduction values at the two hydrogen peroxide concentrations assessed: $900 \mathrm{mg} \mathrm{L}^{-1}$ (1:5 DOC: $\mathrm{H}_{2} \mathrm{O}_{2}$ ) and $1260 \mathrm{mg} \mathrm{L}^{-1}\left(1: 7 \mathrm{DOC}: \mathrm{H}_{2} \mathrm{O}_{2}\right.$ ). The best result was around 95\% DOC reduction at the 1:5 DOC: $\mathrm{H}_{2} \mathrm{O}_{2}$ mass ratio with the $\mathrm{Fe}$ (II) concentration of $31 \mathrm{mg} \mathrm{L}^{-1}$. A similar result (94\%) was obtained using the highest $\mathrm{H}_{2} \mathrm{O}_{2}$ concentration and the same $\mathrm{Fe}(\mathrm{II})$ concentration (31 $\left.\mathrm{mg} \mathrm{L}^{-1}\right)$. The highest efficiency for the COD parameter
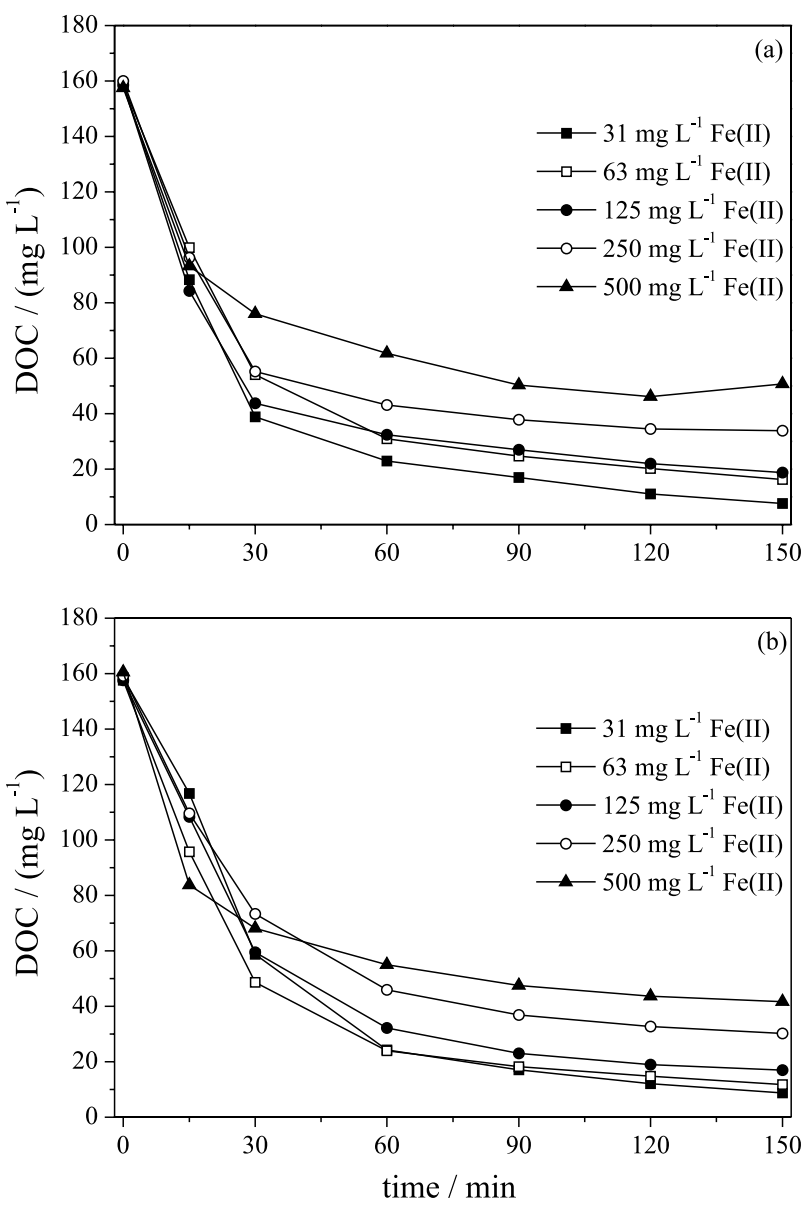

Figure 4. DOC values at different $\mathrm{Fe}$ (II) concentrations over time for (a) 1:5 and (b) 1:7 DOC: $\mathrm{H}_{2} \mathrm{O}_{2}$ mass ratios for the photo-Fenton process. 
was also achieved using a concentration of $31 \mathrm{mg} \mathrm{L}^{-1} \mathrm{Fe}(\mathrm{II})$ for both DOC: $\mathrm{H}_{2} \mathrm{O}_{2}$ mass ratios.

\section{Comparison between the processes}

Figure 5 shows the results of DOC reduction of stripped sour water subjected to photolysis, peroxidation, peroxidation assisted by ultraviolet light, Fenton and photoFenton processes for $210 \mathrm{~min}$ of testing.

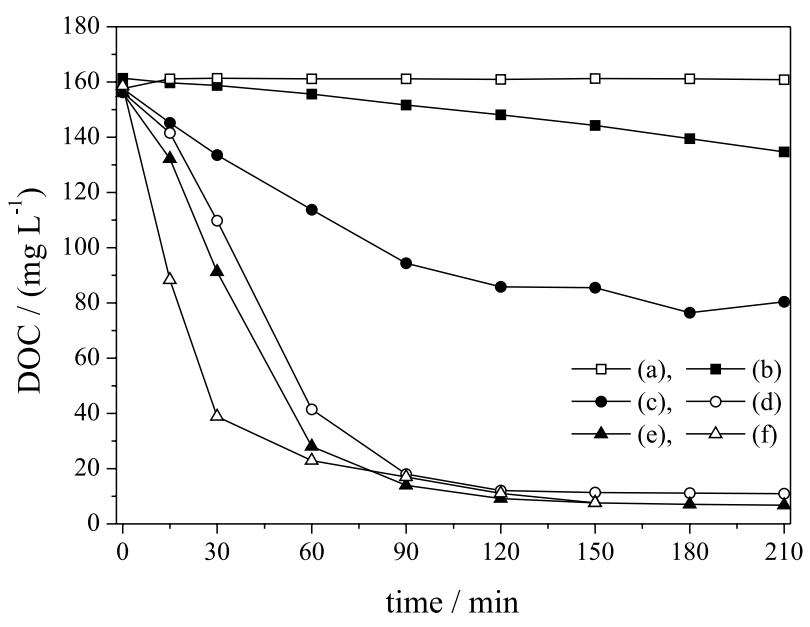

Figure 5. DOC value variation over time during treatment by (a) $\mathrm{H}_{2} \mathrm{O}_{2}$ (DOC: $\mathrm{H}_{2} \mathrm{O}_{2}$ 1:7 mass ratio), (b) UV, (c) Fenton's reagent (250 $\mathrm{mg} \mathrm{L}^{-1}$ $\mathrm{Fe}(\mathrm{II})$ and DOC: $\mathrm{H}_{2} \mathrm{O}_{2} 1: 7$ mass ratio), (d) $\mathrm{UV} / \mathrm{H}_{2} \mathrm{O}_{2}$ (DOC: $\mathrm{H}_{2} \mathrm{O}_{2} 1: 5$ mass ratio), (e) $\mathrm{UV} / \mathrm{H}_{2} \mathrm{O}_{2}$ (DOC: $\mathrm{H}_{2} \mathrm{O}_{2}$ 1:7 mass ratio) and (f) photo-Fenton (31 $\mathrm{mg} \mathrm{L}^{-1} \mathrm{Fe}(\mathrm{II})$ and DOC: $\mathrm{H}_{2} \mathrm{O}_{2}$ 1:5 mass ratio).

The maximum DOC reduction by photolysis after 210 min was $17 \%$, while peroxidation was not able to reduce DOC concentration, independent of the concentration of peroxide used ( 360 to $1260 \mathrm{mg} \mathrm{L}^{-1}$ ).

For the $\mathrm{UV} / \mathrm{H}_{2} \mathrm{O}_{2}$ process, in $210 \mathrm{~min}$ of reaction, DOC reduction efficiency at 1:5 DOC: $\mathrm{H}_{2} \mathrm{O}_{2}$ was $93 \%$, while it was $98 \%$ at a $1: 7$ mass ratio, and COD removal efficiencies were $95 \%$ for $1: 5$ DOC: $\mathrm{H}_{2} \mathrm{O}_{2}$ and $99 \%$ for a $1: 7$ mass ratio. Maximum color reduction was $42.3 \%$. However, this process was not effective at reducing turbidity (maximum $4.0 \%$ ). The reactions were definitely more significant for dissolved compounds.

By using 1:7 DOC: $\mathrm{H}_{2} \mathrm{O}_{2}$ mass ratio and $250 \mathrm{mg} \mathrm{L}^{-1}$ of Fe(II), DOC was reduced $45 \%$ in 120 min for Fenton's reagent. After that time, reduction efficiency stabilized. DOC removal was $95 \%$ for the photo-Fenton process using $31 \mathrm{mg} \mathrm{L}^{-1}$ ferrous ion and a 1:5 DOC: $\mathrm{H}_{2} \mathrm{O}_{2}$ mass ratio in 150 min of reaction.

It can be concluded that, considering the total testing time of 210 min, peroxidation, photolysis and Fenton's reagent processes were not very efficient at degrading the organic compounds found in stripped sour water. Photo- mediated processes using $\mathrm{UV}$ radiation $\left(\mathrm{UV} / \mathrm{H}_{2} \mathrm{O}_{2}\right.$ and photo-Fenton) offered the most efficient DOC reduction.

\section{Potential reuse of the effluent treated by AOP}

Among the studied processes, peroxidation combined with ultraviolet radiation $\left(\mathrm{UV} / \mathrm{H}_{2} \mathrm{O}_{2}\right)$ presented as a promising process to treat stripped sour water for the purpose of reusing. The photo-Fenton process also resulted in the reduction of most of DOC from stripped sour water (as shown in Figure 5). However, here are some disadvantages in the use of the photo-Fenton process. The $\mathrm{pH}$ value must be adjusted at the beginning and at the end of the reaction and precipitated iron hydroxide has to be removed as well, generating additional costs. Another restriction may relate to high electrical conductivity values of the effluent treated by photo-Fenton, around $1200 \mu \mathrm{S} \mathrm{cm}^{-1}$, which could significantly reduce the possibilities of reusing of this effluent.

By comparing the two DOC: $\mathrm{H}_{2} \mathrm{O}_{2}$ mass ratios in peroxidation assisted by ultraviolet radiation (Figure 5), it can be concluded that the best treatment option is using the DOC: $\mathrm{H}_{2} \mathrm{O}_{2}$ 1:5 ratio. This conclusion took the economy of hydrogen peroxide into account since the efficiency of both treatments was very similar.

One possibility for reusing the stripped sour water treated by peroxidation assisted by ultraviolet radiation (1:5 DOC: $\mathrm{H}_{2} \mathrm{O}_{2}$ mass ratio) would be as replacement water in the cooling towers since they are responsible for consuming $49 \%$ of the water collected from the Jaguari River by Replan Refinery in Paulínia City. Table 2 shows the parameters analyzed for raw effluent and that treated by the $\mathrm{UV} / \mathrm{H}_{2} \mathrm{O}_{2}$ process compared with values recommended by US EPA (United State Environmental Protection Agency) for cooling tower feedwater. ${ }^{37}$ It is worth mentioning that there is no legislation governing water reuse in Brazil.

Table 2. Characterization of stripped sour water before and after treatment by $\mathrm{UV} / \mathrm{H}_{2} \mathrm{O}_{2}$ process (DOC: $\mathrm{H}_{2} \mathrm{O}_{2} 1: 5$ mass ratio; $210 \mathrm{~min}$ of reaction) and recommended values for replacement water in cooling towers (adapted from Oenning Jr. and Pawlowsky $)^{38}$

\begin{tabular}{|c|c|c|c|c|}
\hline \multirow[b]{2}{*}{ Parameters } & \multirow[b]{2}{*}{ Units } & \multicolumn{2}{|c|}{ Results } & \multirow{2}{*}{$\begin{array}{l}\text { Recommended } \\
\text { limits for } \\
\text { cooling water }\end{array}$} \\
\hline & & Raw & Treated & \\
\hline$\overline{\mathrm{COD}}$ & $\mathrm{mg} \mathrm{O}_{2} \mathrm{~L}^{-1}$ & 553 & 15 & $\leq 75^{\mathrm{a}}$ \\
\hline BOD & $\mathrm{mg} \mathrm{O}_{2} \mathrm{~L}^{-1}$ & 147 & n.p. & $\leq 30^{\mathrm{b}}$ \\
\hline DOC & $\mathrm{mg} \mathrm{L}^{-1}$ & 160.5 & 10.9 & n.f. \\
\hline $\mathrm{EC}$ & $\mu \mathrm{S} \mathrm{cm}{ }^{-1}$ & 396 & 520 & $800-1200^{c}$ \\
\hline $\mathrm{pH}$ & & 9.5 & 8.2 & $6-9^{b}$ \\
\hline Turbidity & UT & 30 & 29.8 & $\leq 3.0^{\mathrm{d}}$ \\
\hline $\begin{array}{l}\text { Apparent } \\
\text { color }\end{array}$ & $\mathrm{PtCo}$ & 624 & 428 & n.f. \\
\hline
\end{tabular}


By comparing the values of the parameters analyzed with the recommended limits for replacement water in cooling towers, it can be seen that the only parameter that does not fit is the turbidity value, which is much higher than the recommended one. The other values are within the range recommended in literature. ${ }^{37,39} \mathrm{It}$ is important to emphasize that no information was found on the recommended values for DOC and color parameters.

Therefore, in order to make the reuse of stripped sour water treated by $\mathrm{UV} / \mathrm{H}_{2} \mathrm{O}_{2}$ process feasible as replacement water in the cooling towers, it would be necessary to pretreat the water to reduce turbidity. The pre-treatment could be performed by means of a physical process. Furthermore, studies involving scale-up are of fundamental importance. However, a more detailed and thorough study would be indispensable in order to select the most appropriate technique, in addition to careful economic evaluation and monitoring to avoid damaging the cooling system.

\section{Conclusions}

The photo-irradiated advanced oxidation processes (photo-Fenton and peroxidation assisted by ultraviolet radiation) were highly effective at reducing DOC in stripped sour water. The photo-Fenton process $\left(\mathrm{H}_{2} \mathrm{O}_{2} / \mathrm{Fe}(\mathrm{II}) / \mathrm{UV}\right)$ was able to reduce $95 \%$ of DOC when $31 \mathrm{mg} \mathrm{L}^{-1}$ of $\mathrm{Fe}(\mathrm{II})$ were used at a 1:5 DOC: $\mathrm{H}_{2} \mathrm{O}_{2}$ mass ratio. DOC reduction efficiency by $\mathrm{UV} / \mathrm{H}_{2} \mathrm{O}_{2}$ was nearly $95 \%$ when $1: 5,1: 6$ and 1:7 DOC: $\mathrm{H}_{2} \mathrm{O}_{2}$ mass ratios were employed.

Finally, the peroxidation assisted by ultraviolet radiation (1:5 DOC: $\mathrm{H}_{2} \mathrm{O}_{2}$ mass ratio) presented high potential for the treatment of stripped sour water for the purpose of its reuse as replacement water in cooling towers after being treated to reduce turbidity. However, scale-up studies are necessary for proper management of the treated effluent.

\section{Acknowledgements}

The authors would like to thank Petrobras and Coordenação de Aperfeiçoamento de Pessoal de Nível Superior (CAPES) for providing scholarships to M. C. Gasparini and M. G. Maniero (PNPD 0233080).

\section{References}

1. Saien, J.; Nejati, H.; J. Hazard. Mater. 2007, 148, 491.

2. United States Environmental Protection Agency (US EPA); Profile of the Petroleum Refining Industry; Office of Compliance Sector Notebook Project: Washington D.C, September, 1995, http:// www.epa.gov/compliance/resources/publications/assistance/ sectors/notebooks/petrefsn.pdf accessed in August 2012.
3. Coelho, A.; Castro, A. V.; Dezotti, M.; Sant'Anna Jr., G. L.; J. Hazard. Mater. 2006, B137, 178.

4. Malato, S.; Blanco, J.; Vidal, A.; Alarcón, D.; Maldonado, M. I.; Cáceres, J.; Gernjak, W.; Sol. Energy 2003, 75, 329.

5. Maniero, M. G.; Bila, D. M.; Dezotti, M.; Sci. Total Environ. 2008, 407, 105.

6. Wang, L.; Barrington, S.; Kim, J.-W.; J. Environ. Manage. 2007, 83, 191.

7. Rahman, M. M.; Al-Malack, M. H.; Desalination 2006, 191, 16.

8. El-Naas, M. H.; Al-Zuhair, S.; Al-Lobaney, A.; Makhlouf, S.; J. Environ. Manage. 2009, 91, 180.

9. Stepnowski, P.; Siedlecka, E. M.; Behrend, P.; Jastorff, B.; Water Res. 2002, 36, 2167.

10. Santos, M. R. G.; Goulart, M. O. F.; Tonholo, J.; Zanta, C. L. P. S.; Chemosphere 2006, 64, 393.

11. Yavuz, Y.; Koparal, A. S.; Öğütveren, Ü. B.; Desalination 2010 , 258, 201.

12. Sun, Y.; Zhang, Y.; Quan, X.; Sep. Purif. Technol. 2008, 62, 565.

13. Bhargava, S. K.; Tardio, J.; Jani, H.; Akolekar, D. B.; Föger, K.; Hoang, M.; Catal. Surv. Asia 2007, 11, 70.

14. Prasad, J.; Tardio, J.; Jani, H.; Bhargava, S. K.; Akolekar, D. B.; Grocott, S. C.; J. Hazard. Mater. 2007, 146, 589.

15. Ismail, Z. Z.; Al-Hashimi, E. A.; J. Clean. Prod. 2011, $19,197$.

16. El-Salam, M. M.; El-Naggar, H. M.; J. Clean. Prod. 2010, 18, 1403.

17. Oliveira, K. D.; Cardoso, M.; Nicolato, R.; Lat. Am. Appl. Res. 2010, 40, 81 .

18. De Feo, G.; Rizzo, L.; Belgiorno, V.; Meric, S.; Int. J. Environ. Pol. 2006, 28, 100.

19. Da Silva, C. R.; Maniero, M. G.; Rath, S.; Guimarães, J. R.; J. Adv. Oxid. Technol. 2011, 14, 106.

20. Guimarães, J. R.; Santos, L. U.; Assalin, M.; Figueiredo, R. F.; Rev. DAE 2010, 184, 35.

21. American Public Health Association (APHA), American Water Works Association (AWWA), Water Environment Federation (WEF); Standard Methods for Examination of Water and Wastewater, 21 $1^{\text {th }}$ ed.; American Public Health Association: Washington D.C., 1998.

22. ASTM D1293: Standard Test Methods for $p H$ of Water, American Society for Testing and Materials, Philadelphia, 1999.

23. Nogueira, R. F. P.; Oliveira, M. C.; Paterlini, W. C.; Talanta 2005, 66, 86 .

24. Abramovic, B. F.; Banic, N. D.; Šojic, D. V.; Chemosphere 2010, 81, 114.

25. Ghodbane, H.; Hamdaoui, O.; Chem. Eng. J. 2010, 160, 226.

26. Silva, T. C. F.; Silva, C. M.; Reis, C.; Bellato, C. R.; Lucia, L. A.; Ind. Eng. Chem. Res. 2010, 49, 11214.

27. Daneshvar, N.; Rabbani, M.; Modirshahla, N.; Behnajady, M.A.; Chemosphere 2004, 56, 895. 
28. De Souza, D. R. D.; Duarte, E. T. F. M.; Girardi, G. D. S.; Velani, V.; Machado, A. E. D. H.; Sattler, C.; Oliveira, L. D.; Miranda, J. A. D.; J. Photochem. Photobiol., A 2006, 179, 269.

29. Maciel, R.; Sant'Anna Jr., G. L.; Dezotti, M.; Chemosphere 2004, 57, 711.

30. Domènech, X.; Jardim, W. F.; Litter, M. I. In Eliminación de Contaminantes por Fotocatálisis Heterogênea; Blesa, M. A., ed.; Red CYTED VIII-G: Buenos Aires, Argentina, 2001.

31. Mota, A. L. N.; Albuquerque, L. F.; Beltrame, L. T. C.; Chiavone-Filho, O.; Machulek Jr., A.; Nascimento, C. A. O.; Braz. J. Pet. Gas 2008, 2, 122.

32. Padoley, K. V.; Mudliar, S. N.; Banerjee, S. K.; Deshmukh, S. C.; Pandey, R. A.; Chem. Eng. J. 2011, 166, 1.

33. Yang, M.; Hu, J.; Ito, K.; Environ. Technol. 1998, 19, 183.

34. Zang, Y.; Pagilla, K.; Desalination 2010, 263, 36.

35. Saritha, P.; Aparna, C.; Himabindu, V.; Anjaneyulu, Y.; J. Hazard. Mater. 2007, 149, 609.
36. Ghaly, M. Y.; Härtel, G.; Mayer, R.; Haseneder, R.; Waste Manage. 2001, 21, 41.

37. United States Environmental Protection Agency (US EPA); Guidelines for Water Reuse; US Agency for International Development: Washington D.C., September, 2004, http:// www.ehproject.org/PDF/ehkm/water-reuse2004.pdf accessed in August 2012.

38. Oenning Jr., A.; Pawlowsky, U.; Eng. Sanit. Ambient. 2007, 12, 305.

39. Tchobanoglous, G.; Burton, F. L.; Stensel, H. D.; Wastewater Engineering: Treatment and Reuse, $4^{\text {th }}$ ed.; Metcalf \& Eddy: New York, 2003.

Submitted: May 31, 2012

Published online: August 30, 2012

FAPESP has sponsored the publication of this article. 